\title{
The Effects of Corporate Social Responsibility (Csr) on Corporate Brand Positioning
}

\author{
Africa Makasi \\ PhD student, University of KwaZulu-Natal, South Africa and Harare Institute of Technology, Zimbabwe \\ africa.makasi@yahoo.com
}

Krishna Govender

University of KwaZulu-Natal, South Africa and Regenesys Business School, South Africa

Tendai Munyoro

Midlands State University, Zimbabwe (MBA student).Africa Makasi. Harare Institute of Technology. Department of Technopreneurship, Zimbabwe. P.O. Box B.E 277.Belvedere, Harare, Zimbabwe.

Email: africa.makasi@yahoo.com

\section{Doi:10.5901/mjss.2014.v5n20p2597}

\section{Abstract}

\begin{abstract}
The purpose of this paper was to investigate the role of Corporate Social Responsibility (CSR) in corporate brand positioning in the printing and packaging industry in Zimbabwe. The research was conducted by reviewing various streams of literature and interviews with 10 representatives from 5 companies and 10 customers also participated in this research. A semi-structured questionnaire was used. Two representatives from each of the ten competing companies were selected while customer representatives (both industrial and ordinary) were selected using the companies' customer records as the sampling frame. These were selected on the basis of the ratio of their revenue contribution which stands at 1: 2 in favour of industrial customers. All qualitative responses were grouped into themes for coding purposes. The data gathered was coded and captured to form panel data for further analysis using the Statistical Package for Social Sciences (SPSS) version 19. Results of the research indicated that 15 out of the sampled respondents of 20 confirmed that indeed CSR directed towards employees through provision of health care services and education and other activities as highlighted help to improve corporate image and position. The research also concluded that communities are intertwined with companies and their perceptions matter in corporate brand positioning. Using results of the T-Tests, it was concluded that CSR programs directed towards the environment play an important role in positioning corporate brands. Future research can refine CSR input by recognizing these differences and theorizing about employees' reactions.
\end{abstract}

Keywords: corporate social responsibility, corporate brand, corporate image, positioning.

\section{Introduction}

Zimbabwe's printing and packaging industry sector has been virtually invisible in the market despite its strategic significance in the provision of printed materials to the entire economy (Mushanyuri, 2013). Instead, it has been other sectors which continue to take center stage; mainly companies in the beverages industry, the banking sector and lately the Information Communication Technology (ICT) industry. This is despite evidence that managers need to be receptive to the evolving needs of stakeholders, and proactive in addressing these to retain a strong market position (Low and Fullerton, 1994). In contemporary society, brand managers can no longer dictate the needs of consumers. Stakeholders are increasingly demanding, and as a result corporate social responsibility is becoming an operating requirement (Joyner and Payne, 2002).While many corporate leaders recognize the need for a multiple-stakeholder focus, they have little evidence to satisfy baseline expectations associated with corporate social responsibility. This lack of knowledge about the phenomenon provoked the need for the study.

\section{Literature Review}

The concept of corporate social responsibility (CSR) has a long and varied history (Carroll, 1999). In the early stages, CSR mainly focused on economic model as an invisible hand (Smith, 1790). He points out that every individual in society 
intend to promote its goods and services through the marketplace. As the business responses to the market's demand, it is rewarded on greatest value and profitability. Thus, it is apparently that the 'invisible hand' concept transforms selfinterest into societal interest. The evolution of CSR in 1950s is mainly known as the social responsibility (SR) more than as CSR because the corporate had not yet occurred (Carroll, 1999). Bowen (1953) firstly points out the emergence of social responsibility to CSR into the seminal book 'Social Responsibilities of the Businessmen. The development of CSR in 1970s, most scholars attempts to define the meaning of CSR in both academic and non-academic terms. Similar to earlier scholars, Heald (1970) proposed CSR relates to businessmen. In 1979, Carroll (1979) proposes the outstanding CSR concepts based on fours levels; economic, legal, ethical and discretionary (philanthropic) expectations. Similar to Carroll's concept, Thorne et al., (2005) assert that CSR has a basic motivation from three perspectives namely economic perspective, strategic perspective and ethical perspective. In the sense of economic and strategic motivations, most companies attempt to create the long-term profit maximization by outweighing cost and benefit of CSR activities (Friedman, 1970). There are many theories which support the economic view such as theory of the firm (McWilliams and Siegel, 2001), Stakeholder theory (Mitchell et al., 1997), whereas the strategic perspective are supported by the theories such as resource-based view of the firm and capabilities (Hart, 1995) and competitive advantage in terms of investment in social activities (Porter and Kramer, 2002) and value created (Burke and Logsdon, 1996). On the other hand, the ethical view, the companies focus on the right thing to practice toward society. The example of ethical approach such as the stakeholder normative theory which explain the reason why the managers should consider stakeholders' interests (Freeman, 1984; Donaldson and Preston, 1995) and the sustainable development which is aimed at human development (Gladwin et al., 1995). In the past, the corporate social responsibility (CSR) phenomenon has been widely explored in terms of its contributions to the success of corporations in their respective industries (Carroll, 1998; Dowling, 2004; Gomez, 2002; Gupta, 2002; Kinard, Smith, \& Kinard, 2003; Mercer, 2003). Freeman (1984) however, looked at CSR as best undertaken by considering all the stakeholders relevant in conducting business. He developed the stakeholder theory. The stakeholder theory assumes that stakeholders are influential as they can either give support in terms of purchasing habits, showing loyalty and praising the company, or they can show opposition in terms of demonstrating, striking or boycotting the company (Smith 2003). Consequently, and in line with Freeman (1984), this research will adopt the stakeholder perspective by closely scrutinizing the impact of CSR on both the internal stakeholders.

\subsection{Corporate Communication and its effect on consumer perceptions}

Messages about corporate ethical and socially responsible initiatives are likely to evoke strong and often positive reactions among stakeholders (Maignan et al. 1999). Research has even pointed to the potential business benefits of the internal and external communication of corporate social responsibility (CSR) efforts (Maignan et al. 1999). However, while CSR is generally associated with positive corporate virtues and reflects an organization's status and activities with respect to its perceived societal obligations (Brown \& Dacin 1997), corporate CSR messages have also proven to attract critical attention. In fact, research suggests that the more companies expose their ethical and social ambitions, the more likely they are to attract critical stakeholder attention (Ashforth \& Gibbs 1990, Vallentin 2001). Other studies have triggered questions such as 'if a company focuses too intently on communicating CSR associations, is it possible that consumers may believe that the company is trying to hide something?' (Brown \& Dacin 1997: 81). Furthermore, stakeholder expectations regarding CSR are a moving target and must be considered carefully on a frequent basis. The stakeholder information model assumes that stakeholders are influential as they can either give support in terms of purchasing habits, showing loyalty and praising the company, or they can show opposition in terms of demonstrating, striking or boycotting the company (Smith 2003). Therefore, the company must inform stakeholders about its good intentions, decisions and actions to ensure positive stakeholder support.

\subsection{Reviewing the meaning of corporate branding}

There is little agreement in the literature as to what constitutes a corporate brand. According to Balmer and Gray (2003) corporate brands are marks denoting ownership; image-building devices; symbols associated with key values; means by which to construct individual identities; and a conduit by which pleasurable experiences may be consumed. Knox and Bickerton (2003:1013) proposed the following definition of corporate brand, "A corporate brand is the visual, verbal and behavioural expression of an organization's unique business model". In an attempt to differentiate between the constructs of corporate brand and corporate reputation, Corkindale and Belder (2009) note that the focus of the corporate brand building focuses on relevancy to customers whereas reputation concentrates on legitimacy of the organization with respect to the stakeholders. Hatch and Schultz (2001) state that the corporate brand contributes not only to customer- 
based images of the organization, but to the images formed and held by all its stakeholders. Argenti and Druckenmiller (2004), note that a company engages in corporate branding when it markets the company itself as a brand. They state further that the reputation of the organization is strengthened when the corporate brand promise is kept. According to Balmer and Gray (2003), corporate brands are different to product brands in terms of disciplinary scope and management, and have a multi-stakeholder rather than customer orientation. They acknowledge that the terms corporate brands and corporate identities are used interchangeably, but argue that there are fundamental differences between them. According to Balmer and Gray (2003), corporate identity refers to the distinct attributes of an organization which addresses the questions, "who are we? And what are we?" and is relevant to all types of organizations. They go on to state that corporate brands on the other hand are not applicable to all organizations, and would not for example, be necessary for a monopoly (Balmer and Gray, 2003). Organizations seeking to build strong corporate brands must align their internal communications activities and human resource management practices with the brand values (Gotsi and Wilson, 2001). Strategies of corporate branding seek to strengthen relationships with a diverse range of stakeholders including employees, shareholders and suppliers (Harris and de Chernatony, 2001; Knox and Bickerton, 2003). In the quest to achieve long-lasting relationships with internal and external stakeholders the focus advances from the product to that of the corporation (Hatch and Schultz, 2003; Merrilees and Miller, 2008; Xie and Bogs, 2006). In taking centre stage, the corporation can no longer hide behind product actors; instead, as the lead actor, it must consistently deliver the brand promise to each stakeholder. Thus, as the audience for the brand reaches beyond the consumer (King, 1991; Knox and Bickerton, 2003), top management must develop and preside over a strong strategic corporate brand perspective (Hatch and Schultz, 2003; Merrilees and Miller, 2008).

\subsection{Incorporating CSR into corporate branding}

Increasingly, management recognizes the need to promote socially responsible business practices to achieve a sustained strategic advantage (Luo and Bhattacharya, 2006; Sen, Bhattacharya, and Korschun, 2006) and to enhance a corporation's reputation. Reputation, which is the perceptions of all relevant stakeholders (Miles and Govin, 2000) formed through a corporation's actions is an invaluable intangible asset. Corporations through strengthening and protecting the brand's reputation can communicate their credibility (Herbig and Milewicz, 1995) to stakeholders (Maignan, Ferrell, and Ferrell, 2005). Additionally, a plethora of academic research is devoted to corporate social responsibility, its impact, outcome and benefit (Sen et al., 2006). Corporations wanting to attract potential stakeholders are showcasing actions that further a particular social good (Castaldo et al., 2009). However, engaging in corporate social responsibility with the wrong motives can potentially undermine the corporate brand identity and adversely affect a brand's established reputation. Knowledgeable stakeholders, especially consumers (Miller, 2008), are alert to the inauthentic actions of corporations. McWilliams and Siegel (2001) argue that corporate social responsibility involves going beyond the legal requirements. By investing in corporate social responsibility, corporations can secure competitive advantages, financial benefits (Luo and Bhattacharya, 2006), build brand awareness (Hoeffler and Keller, 2002) and create brand legitimacy (Luo and Bhattacharya, 2006; Uggla, 2006; Vaaland et al., 2008; Werther Jr and Chandler, 2005), which can in turn strengthen the relationship of stakeholders with the corporate brand. However, few corporations fully leverage the brand building opportunities that corporate social responsibility offers (Blumenthal and Bergstrom, 2003). According to Firestein (2006), reputation is the strongest determinant of any organization's sustainability. While strategies can always be changed, when reputation is gravely injured, it is difficult for an organization to recover. Reputation is rooted in the aggregated perceptions of the organization's stakeholders (Fombrun, Gardberg, and Sever, 2000). Fombrun and van Riel (2003) suggest that organizations with good reputations attract positive stakeholder engagement. A favorable corporate reputation results in business survival and profitability (Roberts and Dowling, 2002), is an effective mechanism to maintain competitive advantage, and can aid in buildling customer retention and satisfaction (Caminiti, 1992) and obtaining favourable media coverage (Fombrun et. al., 2000).

\subsection{What Corporate brand Positioning entails}

Branding is about creating a unique position and distinguishing the corporation from its rivals. Schmidt and Ludlow ( 2002) defined positioning as it is normally used in marketing to denote the distinctive market position which a brand has, or wishes to have, in relation to its competition. They presented a holistic approach to positioning. Keller (2000) identified some characteristics for a successful brand which is effectively positioned. And De Chernatony and McDonald (2003) explored the two types of competitive brand advantage: cost-driven and value-added. Positioning is the differentiation of brand or product according to the target market' perception relative to similar offerings in the given markets. All elements 
of a company's behavior affect the position in customers' minds. Tadevosyan et al (2008) argued that there was a lake of research about corporate brand positioning, while previous researchers had focused on product brand positioning. In general, brand positioning refers to consumers' perceptions and insights about a special brand as well as the niche the brand occupies in their mind. Chew (2009) differentiated between strategic positioning, strategic position and positioning strategy since the term 'position' has a variety of meanings in the literature. Strategic positioning is synonymous with positioning in the literature and is a process of defining and maintaining a distinctive place in the market for organization, operation, and assessing organization position relative to competitors (Zineldin and Bredenlow, 2001). Several authors suggested two approaches to strategic position: internal organization and external target audience (Reddy and Campbell, 1993; Hooley 2001; Fill 2002; Attia 2003). Strategic position of a corporation is the outcome of decisions made at the corporate level and is influenced by the external environment, such as availability of internal resources and core competences, and the expectations of various internal and external stakeholders (Johnson, Scholes and Whittington, 2006). Strategic position also provides direction for operational positioning. However, positioning at the product/brand or operational level involves identifying how the organization's offerings are perceived by its users/consumers relative to other competing products or brands. Additionally, it develops appropriate marketing mix strategies that support their position in the marketplace (Chew, 2009). Chew (2009) noted that research should assess how investments directed towards internal as well as external stakeholders help in shaping corporate identities. Therefore, the gap in research is to find out how CSR influences corporate positioning. This is closely in line with the research objectives stated before.

\subsection{Stakeholder theory and its relevance in brand positioning}

While the stakeholder model was introduced to management theory many years ago by Freeman (1984), stakeholder management has developed into one of current management theory's most encompassing concepts (e.g. Donaldson \& Preston 1995, Mitchell et al. 1997, Stoney \& Winstanley 2001). Freeman's (1984: 25) 'stakeholder view of the firm' instrumentally defines a stakeholder as 'Any group or individual who can affect or is affected by the achievement of the firm's objectives' and he suggests that there is a need for 'integrated approaches for dealing with multiple stakeholders on multiple issues' (1984: 26). While Freeman (1984) framed and demarcated stakeholders as elements of corporate strategic planning, he most importantly demonstrated the urgency of stakeholders for the mission and purpose of the company, and in doing so, also suggested the positive financial implications of better relationships with stakeholders. In line with Freeman's thinking, many other scholars have pursued exploration of the link between corporate social performance and financial performance (Wood 1991, Pava \& Krausz 1996), but the conclusions so far paint an unclear picture (Margolis \& Walsh 2003).

In recent years, stakeholder theory has developed a focus on the importance of engaging stakeholders in longterm value creation (Andriof et al. 2002). This is a process whose perspective focuses on developing a long-term mutual relationship rather than simply focusing on immediate profit. The emphasis is moved from a focus on stakeholders being managed by companies to a focus on the interaction that companies have with their stakeholders based on a relational and process-oriented view (Andriof \& Waddock 2002: 19). This implies an increased interest in understanding how managers can manage not the stakeholders themselves, but relationships with stakeholders. Stakeholder relationships have even been suggested as a source of competitive advantage (Andriof \& Waddock 2002, Post et al. 2002, JohnsonCramer et al. 2003) as those companies with strong relations to other organizations, institutions and partners are in a better position to develop relational rents through relation specific assets, knowledge-sharing routines, complementary resource endowments and effective governance (Dyer \& Singh 1998). As argued by Johnson-Cramer et al. (2003: 149) 'The essence of stakeholder dialogue is the co-creation of shared understanding by company and stakeholder'. Therefore with close guidance from available literature, this research extends current research by exploring how internal and external stakeholders evaluate a company's image and positioning.

\subsection{The role of CSR and its stakeholders}

The employee is one of the most significant stakeholders (Redington 2005). However, the notion of the importance of the employee as a stakeholder is conspicuously absent from management discussion (De Cieri et al. 2005; Pinnington et al. 2007). Employee motivation is usually discussed based on the notion that workers are not motivated only by the need for money and that non-financial elements are also important for employee motivation (Frey 1997). CSR in marketing initiatives have a significant impact on the employees' mind-set. CSR in marketing is compelling and fosters a positive implication of the overall corporate brand on the minds of the aspiring candidates. Thus more people desire to be associated with it. Existing employees take pride in their employer's brand and feel more committed towards their work 
and thus tend to have elongated service tenure (Bhattacharya, Sen and Korschun, 2007). Post et al. (2002) argue that the relationship between firms and stakeholders is the sources of a firm's wealth and long-term success since stakeholders are critical resources that have power to impact on firms' achievement. Employees as a unit of analysis have received limited attention in past CSR literature (Aguilera et al., 2007: 839; Rupp et al., 2006; Swanson \& Niehoff, 2001). Past CSR and HRM research has mainly focused on relationships between leadership and corporate social behavior (Swanson, 2008; Waldman, Siegel \& Javidan, 2006), or defined socially responsible leadership (Waldman \& Siegel, 2008).

External stakeholders are equaly important (Smidts, Pruyn, \& Riel, 2001; Pratt, 1998). Researchers have studied the process by which Individuals identify their selves with an organization (Lichtenstein, Drumwright, \& Braig, 2004). Dutton et al. (1994) define "organizational identification" as a perceptional link between the identification of the organization and the individual's self. In this event, the term of identification has moved from the employee prospective to the consumer or external stakeholder (Ahearne, Bhattacharya, \& Gruen, 2005; Bhattacharya \& Sen, 2003; Sen \& Bhattacharya, 2001; Lichtenstein, Drumwright, \& Braig, 2004). Considering this movement, consumers are key stakeholders who play a significant role in establishing the company reputation and identification (Ferrell, 2004).Identification with a company results in a commitment to it, this commitment play a significant role by enhancing positive attitude toward the company, loyal behavior, and repeat buying (Bergami \& Bagozzi, 2000; Brown et al. 2005). Recent studies show that consumer behaviors are positively influenced by customer-company identification (Ahearne et al., 2005; Bhattacharya \& Sen, 2003; Sen \& Bhattacharya, 2001). Based on Bhattacharya and Sen (2003), consumers who identify their selves with the company behave in a way that supports the corporation's goals. This research will thus consider employees as a group which perceives, evaluates and reacts to CSR and also external stakeholders' mediating roles by explaining how CSR-trigger attitudes and behaviors which may affect organizational image and positioning in society.

\section{Methodology}

The general design of the research was quantitative in nature which demanded searching the strategic factors of CSR approaches that influence the conduct of business by companies in printing and packaging industry. Participants willing to take part in the survey were contacted via an e-mail invitation. The interview sessions were semi-structured and the keytopics were addressed with closed ended questions. The research took aim at all the 25 Confederation of Zimbabwe (CZI) registered companies in the printing and packaging industry. However, since the list contains many small an upcoming companies, the research sample was streamlined accordingly. With respect to customers, all industrial and ordinary consumers of printing and packaging products were targeted. This entailed grouping these consumers into their respective clusters from which sample representatives will be selected.

Considering the nature of the research, a purposive sampling method was selected as the most appropriate. The sample size was determined largely through the use of Krejcie and Morgan's model of sample size determination. The population size of industry companies is 25 and according to the model, the sample should be 24 . However, since some companies did not respond, the final sample size was 10 companies. The questionnaire was designed in a semistructured nature around the stated research objectives. This was deliberately done to ensure that only relevant questions which help in providing answers to research questions were asked. The semi-structured nature of the questionnaire allowed the use of both closed ended as well as open -ended questions. The use of open and closed questions was deliberately designed in order to be able to obtain both quantitative as well as qualitative data. This way, the researcher was able to triangulate the research results. The open questions were useful in exploring new areas or ones in which the researcher had limited knowledge since the respondents could answer however they wish. Conversely, closed questions enhanced comparability of answer since they are presented with a set of fixed alternatives from which they had to choose an appropriate answer. The draft questionnaire was initially be given to colleagues for scrutiny before it is presented to a few selected customers for further pilot testing. Amendments to the questionnaire were made accordingly resulting in designing of the final questionnaire to be used in this research.

\subsection{Validity and reliability of findings}

Reliability is defined as the extent to which results are consistent over time and an accurate representation of the total population under study. If the results of a study can be reproduced under a similar methodology, then the research instrument is considered to be reliable. Consistent with the above, reliability of research was achieved through instrument pilot testing. Further, in order to test instrument reliability, Cronbach's Alpha was calculated using the Statistical Package 
for Social Sciences (SPSS). Validity determines whether the research truly measures that which it was intended to measure or how truthful the research results are. For this reason, data triangulation was in order to control bias and establishing valid propositions because traditional scientific techniques are incompatible with this alternate epistemology. As a result, the researcher combined both quantitative and qualitative techniques in gathering and analyzing research through the use of a semi-structured questionnaire as mentioned. By so doing, triangulation strengthened the study and thus increased its validity. The collected data was analyzed through the use of charts, tables, graphs, diagrams and also content analysis. This entailed a critical analysis of the responses given on order to extract meaning. This process used inductive reasoning, by which themes and categories emerged from the data through the researcher's careful examination and constant comparison.

\section{Findings}

While twenty questionnaires were sent to the sampled companies, five did not complete them at all. Of the remaining 15 questionnaires returned, 5 were not completed in full and were discarded as unusable leaving only 10 usable questionnaires drawn form 5 company representatives as shown on the table below. With respect to consumers, of the 15 expected, only 10 completed and returned the questionnaires. Therefore, the overall response rate was calculated as $57 \%$.

Table 1a: Univariate Analysis of Variance

Between-Subjects Factors

\begin{tabular}{|c|c|c|c|}
\hline & & Value Label & $\mathrm{N}$ \\
\hline Increases corporate image and positioning & $\begin{array}{l}1 \\
2\end{array}$ & $\begin{array}{c}\text { Strongly agree } \\
\text { Agree }\end{array}$ & $\begin{array}{c}15 \\
5\end{array}$ \\
\hline
\end{tabular}

Table $1 \mathrm{~b}$ : Tests of between subjects effects

Tests of Between-Subjects Effects

Dependent Variable's through employees tuition fees

\begin{tabular}{|c|c|c|c|c|c|}
\hline Source & Type III Sum of Squares & df & Mean Square & F & Sig. \\
\hline Corrected Model & .067 a & 1 & .067 & .692 & .416 \\
Intercept & 19.267 & 1 & 19.267 & 200.077 & .000 \\
Benefits5b & .067 & 1 & .067 & .692 & .416 \\
Error & 1.733 & 18 & .096 & & \\
Total & 26.000 & 20 & & & \\
Corrected Total & 1.800 & 19 & & & \\
\hline
\end{tabular}

a. R Squared $=.037$ (Adjusted R Squared $=-.016$ )

In order to strengthen the above results, further analysis of between subject factors revealed a strong correlation with the prediction that by providing schools fees to employees, the company's image and positioning is enhanced. This was confirmed at a significance value of 0.416 and $R^{2}=0.37$. The results as shown on Table $1 \mathrm{a}$ and $1 \mathrm{~b}$ above.

Table 2: One sample T-test

One-Sample Test

\begin{tabular}{|l|c|c|c|c|c|c|}
\hline & \multicolumn{9}{|c|}{ Test Value = 0 } \\
\cline { 5 - 7 } & \multirow{2}{*}{$\mathrm{t}$} & $\mathrm{df}$ & Sig. (2-tailed) & Mean Difference & \multicolumn{2}{|c|}{ 95\% Confidence Interval of the Difference } \\
\cline { 5 - 7 } & & & & & Lower & Upper \\
\hline Builds schools for community & 21.877 & 19 & .000 & 2.300 & 2.08 & 2.52 \\
Builds hospitals for community & 14.038 & 19 & .000 & 1.150 & .98 & 1.32 \\
Helps the disadvantaged & 12.583 & 19 & .000 & 1.250 & 1.04 & 1.46 \\
\hline
\end{tabular}


A one sample T-Test was conducted to assess the effects of three variables namely building schools for the community, building hospitals for community and helping the disadvantaged in society and their relative contribution towards the creation of brand positioning. These test were done at $95 \%$ level of significance. Results showed that while all the three variables are crucial in the building of a strong corporate position, the building of hospitals contributes more with standard deviation of 0.366 . This is followed by the assisted rendered to the disadvantage in society and lastly building schools for the community with a standard deviation of 0.470 abut the mean. This is shown on table 2 above. The significant values of 0.001 on Table 2 show a strong prediction proposed by the analyzed variables.

Table 3a: T-Test for Environmental CSR

\section{One-Sample Statistics}

\begin{tabular}{|l|c|c|c|c|}
\hline & N & Mean & Std. Deviation & Std. Error Mean \\
\hline Using clean energy sources & 20 & 2.30 & .470 & .105 \\
Not polluting the environment & 20 & 1.15 & .366 & .082 \\
Not destroying the environment by cutting down trees & 20 & 1.10 & .308 & .069 \\
\hline
\end{tabular}

Table 3b: One sample T-test for Environmental CSR

\begin{tabular}{|c|c|c|c|c|c|c|}
\hline \multicolumn{7}{|c|}{ One-Sample Test } \\
\hline & \multicolumn{6}{|c|}{ Test Value $=0$} \\
\hline & \multirow[t]{2}{*}{$\mathrm{t}$} & \multirow[t]{2}{*}{ df } & \multirow{2}{*}{$\begin{array}{l}\text { Sig. (2- } \\
\text { tailed) }\end{array}$} & \multirow{2}{*}{$\begin{array}{c}\text { Mean } \\
\text { Difference }\end{array}$} & \multicolumn{2}{|c|}{$\begin{array}{c}95 \% \text { Confidence Interval } \\
\text { of the Difference }\end{array}$} \\
\hline & & & & & Lower & Upper \\
\hline Using clean energy sources & 21.877 & 19 & .000 & 2.300 & 2.08 & 2.52 \\
\hline Not polluting the environment & 14.038 & 19 & .000 & 1.150 & .98 & 1.32 \\
\hline Not destroying the environment by cutting down trees & 15.983 & 19 & .000 & 1.100 & .96 & 1.24 \\
\hline
\end{tabular}

Results relating to the above objective are shown below. A one sample T-Test was conducted to assess the effects of three variables namely using clean energy sources as a way of corporate positioning, not polluting the environment and not destroying the environment through cutting down trees. These test were done at $95 \%$ level of significance. Results showed that while all the three variables are crucial in the building of a strong corporate position, companies which do not pollute the environment and pollute it are better positioned in society. This is reflected by the standard deviations of 0.366 and 0.308 respectively. This is shown on tables $3 \mathrm{a}$ and $3 \mathrm{~b}$ above. The significant values of 0.001 on Table $3 \mathrm{~b}$ all show a strong prediction proposed by the analyzed variables.

Table 4: Correlation analysis

\begin{tabular}{|ll|c|c|}
\hline \multicolumn{2}{|c|}{ Correlations } \\
\hline Not polluting the environment & Not polluting the environment & Good corporate image and positioning \\
& Pearson Correlation & 1 & .031 \\
& Sig. (2-tailed) & & .898 \\
& $\mathrm{~N}$ & 20 & 20 \\
\hline Good corporate image and positioning & Pearson Correlation & .031 & 1 \\
& Sig. (2-tailed) & .898 & 20 \\
$\mathrm{~N}$ & 20 & 20 \\
\hline
\end{tabular}

Using Person's correlation analysis, research results revealed a strong association between not pollution the environment and the company's benefit through the creation of a favourable position in the minds of the community. The strong relationship is reflected by index of 0.31 as shown on Table 4 above.

\section{Discussions}

The research sought to find out if internally directed CSR support programs by a company helps to improve corporate 
brand positioning. 15 out of the sampled respondents of 20 confirmed that indeed CSR directed towards employees through provision of health care services and education and other activities as highlighted in the questionnaire help to improve corporate image and position. It therefore can be concluded that indeed providing such services to employees is good for the corporate positioning. Only 25\% disagreed with this assertion. These results are further strengthened by literature which confirmed that CSR's effect on organizational attractiveness is stronger (Albinger \& Freeman, 2000), and are directly concerned with the issues addressed by CSR (Blackhaus et al., 2002). CSR can, therefore, be seen as a useful marketing tool for attracting and motivating employees and is an important component of corporate reputation (Fombrun \& Shanley, 1990). CSR is a form of corporate investment characterized by a dual orientation towards the improvement of social welfare and of stakeholder relations. This focus on stakeholder relations explains why employees, as a stakeholder group, impact CSR policy. Firstly, employees can act as agents for social change when they push corporations to adopt socially responsible behavior (Aguilera et al., 2007). In addition, results of this research revealed that employee morale is enhanced when a company engages in CSR programmes directed towards the employee. This was reflected by the mean score of 1.2 and a standard deviation of 0.410 . This small deviation revealed a strong confirmation of the tests.

Various streams of literature revealed that employees as a unit of analysis have received limited attention in past CSR researches (Aguilera et al., 2007: 839; Rupp et al., 2006; Swanson \& Niehoff, 2001). It further revealed that past CSR research has mainly focused on relationships between leadership and corporate social behavior (Swanson, 2008; Waldman, Siegel \& Javidan, 2006), or defined socially responsible leadership (Waldman \& Siegel, 2008). Because of the existence of this gap in literature, the above objective was formulated and can safely conclude that indeed CSR has a strong influence on actual employees and how they evaluate and position corporate brands. Therefore, through this research, this gap in literature has finally been closed.

The second objective of this research was to find out the relationship between community CSR and its role in corporate brand positioning. Results produced by the T-Tests through assessing the effects of three variables namely building schools for the community, building hospitals for community and helping the disadvantaged in society and their relative contribution towards the creation of brand positioning showed that while all the three variables are crucial in the building of a strong corporate position, the building of hospitals contributes more with standard deviation of 0.366 . It can be concluded that communities value and appreciate companies which provide services designed to change and improve their lives. This is well supported by literature; for example (Ahearne, Bhattacharya, \& Gruen, 2005; Bhattacharya \& Sen, 2003; Sen and Bhattacharya, 2001; Lichtenstein, Drumwright, and Braig, 2004).

The results showed the importance of external stakeholders in shaping corporate images and their positions society's mind. The stakeholder theory has developed a focus on the importance of engaging stakeholders in long-term value creation. This is a process whose perspective focuses on developing a long-term mutual relationship rather than simply focusing on immediate profit. The emphasis is moved from a focus on stakeholders being managed by companies to a focus on the interaction that companies have with their stakeholders based on a relational and process-oriented view. This implies an increased interest in understanding how managers can manage not the stakeholders themselves, but relationships with stakeholders. If the consumer perception about a company become self-referential or self-definition for, he or she is said to identify with the entity and position it favorably. Although identification develops and grows over time, a person can identify himself/herself with a company or organization that is yet unknown to him or her, if the consumer believed that, the company share the same values.

Available literature did not explicitly expose the role played by external stakeholders in shaping corporate brands and their position in society. Therefore, a research gap existed and had to be closed. The research thus considered external stakeholders' mediating roles by explaining how CSR-trigger attitudes and behaviors which may affect organizational image and positioning in society. Basing on the results of this research, it is concluded that people are more attached and concern about the organization when they identify their self with that organization and that consumer behaviors are positively influenced by company-customer $(c-c)$ identification. Consumers who identify their selves with the company behave in a way that supports the corporation's goals. The range of identification-driven behaviors includes the actions of company promotion, building of hospitals, schools and other amenities as shown by research results. While building on existing literature, the current research has managed to close the gap and conclude that indeed communities are intertwined with companies and their perceptions matter in corporate brand positioning.

Using the results of the T-Test was conducted to assess the effects of three variables namely use of clean energy sources as a way of corporate positioning, not polluting the environment and not destroying the environment through cutting down trees, it was concluded that all the three variables are crucial in the building of a strong corporate position. Companies which do not pollute the environment and destroy it through cutting down trees are better positioned in society. This was reflected by the standard deviations of 0.366 and 0.308 respectively. Further, using the results from 
Pearson's correlation analysis, a strong association between not pollution the environment and the company's benefit through the creation of a favourable position in the minds of the community was established. This implies that the triple bottom line concept (TBL) calls for companies to go beyond profit making motive to environment and society is indeed an important consideration. Evidence suggests proactive environment management enhances firm's market value, reputation, and financial performance. The impact of firms' proactive environmental practices on market share, profitability, and return on investment is better in environmentally conscious companies compared to not-so conscious companies (Ahmed et al., 1998). Business is fundamentally dependent upon society and the environment in which it operates. There is a growing global shift in awareness toward the opportunities that sustainable business practices present corporations.

The gap identified from literature needed to address how environmental programs driven by CSR help corporate brand positioning. For example, while there is an acknowledgement that that businesses depend on the environments in which they operate (Joyner and Payne, 2002; York, 2009), it remained silent on positioning issues hence the need for this research. Strategic positioning is synonymous with positioning in the literature and is a process of defining and maintaining a distinctive place in the market for organization, operation, and assessing organization position relative to competitors. Therefore corporate brand positioning is the outcome of decisions made at the corporate level and is influenced by the external environment, such as availability of internal resources and core competences, and the expectations of various internal and external stakeholders; including the relationship with the environment. This research has managed to close the gap in literature and now conclude that CSR programs directed towards the environment play an important role in positioning corporate brands.

\section{Conclusions}

On the strengths of the research results, it is thus concluded that CSR not only enhances a corporation's reputation for prospective employees by increasing organizational attractiveness and firm familiarity, but also influences incumbent employees. CSR therefore acts as an external marketing and communication function and suggests that it can be a powerful marketing tool for corporations' internal customers - i.e. their employees. Indeed, by enhancing corporate image and organizational prestige in the eyes of external audiences, CSR also affect employees' identification with their corporation. CSR can directly reinforce employees' self-definition and subsequently their identification and subsequently how they position corporate brands. It is therefore recommended that management commit resources to the improvement of employee welfare as this has an implication on corporate positioning. Poor reputation breeds distrust and thus affect organizational performance.

\section{References}

Aguilera, R., Rupp, D. E., Williams, C. A., \& Ganapathi, J. (2007). Putting the s back in corporate social responsibility: A multilevel theory of social change in organizations. Academy of Management Review, 32(3), 836-863.

Albinger, H. S., \& Freeman, S. J., (2000). Corporate social performance and attractiveness as an employer to different job seeking populations, Journal of Business Ethics, 28(3), 243-253.

Andriof, J., S., Waddock, B., and Sutherland, S., (2002). Unfolding Stakeholder Thinking. Theory, Responsibility and Engagement. Greenleaf Publishing, Sheffield. United Kingdom.

Argenti, P.A., and Druckenmiller, B., (2004). Reputation and the Corporate Brand, Journal of Brand Management, 14 (1/2), $137-161$.

Ashforth, B.E., and Gibbs, B.W., (1990). 'The double-edge of organizational legitimation. Organization Science, 1, (2), 177-194.

Attia, S., (2003). Achieving sustainable competitive advantage positioning: the role of resources within environmental constrains. Unpublished thesis, Aston Business School, Birminghham, UK.

Backhaus, K. B., Stone, B. A., and Heiner, K., (2002). Exploring the relationship between corporate social performance and employer attractiveness. Business and Society, 41(3), 292-318.

Balmer, J.M.T., and Gray, E.R., (2003). Corporate brands: What are they? What of them? European Journal of Marketing, 37 (7-8), $972-$ 997.

Bergami, M., and Bagozzi, R. P. (2000). Self-categorization, affective commitment and group self-esteem as distinct aspects of social identity in the organization, British Journal of Social Psychology, 39, 555-577.

Bhattacharya, C. B., and Sen, S., (2003). Consumer-Company Identification: A Framework for Understanding Consumers, Relationship with Companies, Journal of Marketing, 67, 76-88.

Bowen, H. R., (1953). Social Responsibilities of the Businessman, Harper \&Row.

Brown, T.J., Dacin, P.A., Pratt, M.G., and Whetten, D., (2006). Identity, intended image, construed image and reputation: an interdisciplinary framework and suggested terminology, Journal of the Academy of Marketing Science, 34(2), 99-106.

Caminiti, S. (1992). The payoff from a good reputation, Fortune, 125(3), 49-53. 
Carroll, A.B. (1979). A three-dimensional conceptual model of corporate social performance, Academy of Management Review, 4 (4), 497-505.

Carroll, A.B. and Buchholtz A.K. (2003). Business \& Society: Ethics and Stakeholder. Corporate Reputation Review, 6 (4), 368-374.

Castaldo, S., Perrini, F., Misani, N., Tencati, A., (2009). The missing link between corporate social responsibility and consumer trust: The case of fair trade products, Journal of Business Ethics, 84 (1), 1-15.

Chew, C. (2009). Strategic Positioning in Voluntary and Charitable Organizations. New York: Routledge.

Corkindale, D., and Belder, M., (2009). Corporate brand reputation and the adoption of innovations, Journal of Product and Brand Management, 18(4), 242-250.

De Chernatony, L., (2001). A model for strategically building brands, Journal of Product and Brand Management, 21(3), $153-166$.

DeChernatony, L., and McDonald, M., (2003). Creating Powerful Brands. Elsevier/Butterworth. Heinemann, Oxford.

Donaldson, T., (1982). Corporations and Morality. Prentice- Hall, Englewood Cliff, NJ.

Donaldson, T., and Preston, L. E. (1995). The Stakeholder Theory of the Corporation: Concepts, Evidence, and Implications. Academy of Management Review 20 (1), 65-91.

Dowling, D. G., (2004). Corporate Reputations: Should you compete on yours? California Management Review, 46(3), 19-36.

Dutton, J. E., Dukerich J. M., and Harquail C. V., (1994). Organizational images and member Identification, Administrative Science Quarterly, 39 (2), 239-63.

Dyer, J. H., and Singh, H., (1998). The Relational View: Cooperative Strategy and Sources of Interorganizational Competitive Advantage. Academy of Management Review, 23(4), 660-679.

Fill, C., (2002). Marketing Communications: Contexts, Strategies and Applications, New Jersey: Pearson Education.

Firestein, P. J., (2006). Building and protecting corporate reputation, Strategy \& Leadership, 34(4), 25-31.

Fombrun, C., Gardberg, N., and Sever, J., (2000). The reputation quotient: a multi- stakeholder measure of corporate reputation, The Journal of Brand Management, 7 (3), 221-250.

Fombrun, C.J., and van Riel, C.B.M., (2003), Fame and Fortune: How Successful Companies Build Winning Reputations. Prentice-Hall, Upper Saddle River, NJ.

Freeman, R.E., (1984). Strategic Management: A Stakeholders Approach. Boston: Pitman.

Freeman, R.E., and Gilbert, D.R., (1988). Corporate Strategy and the Search for Ethics, Pitman, Boston.

Friedman, A.L., Miles, S., (2002). Developing Stakeholder Theory. Journal of Management Studies 39 (1): 1-21.

Friedman, M., (1970). The social responsibility of business is to increase its profits. New York Times Magazine, September 13, 1970.

Gardberg, N.A., \& Fombrun, C.J., (2002). The global reputation quotient project, first steps towards a cross nationally valid measure of corporate reputation. Corporate Reputation Review, 4, 303-308.

Gladwin, T., Kennelly, J., and Krause, T.S., (1995b). Beyond eco-efficiency: towards socially sustainable business. Sustainable Development 3, 35-43.

Gotsi, M., and Wilson, A., (2001). Corporate reputation: seeking a definition, Corporate Communications, 6(1), 24-30.

Gupta, S., (2002). Strategic Dimensions of Corporate Image: Corporate Ability and Corporate Social Responsibility as Sources of Competitive Advantage via Differentiation, PhD thesis Temple University. United States.

Harris, F., de Chernatony, L., (2001). Corporate branding and corporate brand performance.

Hart, S.L., (1995). A natural-resource-based view of the firm, Academy of Management, 12(4), 5-10.

Hatch, M. J., Schultz, M., (2003). Bringing the corporation into corporate branding, Harvard Business Review, 79(2), 128-134.

Herbig, P., Milewicz, J., (1995). The relationship of reputation and credibility to brand success, Journal of Consumer Marketing, 12 (4), 510.

Hoeffler, S., Keller, K. L., (2002). Building brand equity through corporate societal marketing.

Holley, G.J. (2001). Positioning. In Encyclopedia of Marketing, Thomson Learning. London.

Johnson, G., Scholes, K., and Whittington, R., (2006). Exploring Corporate Strategy (7th edn). Prentice-Hall, England.

Keller, K.L., (2000). Building and managing corporate brand equity. Schultz M, Hatch MJ, Larsen MH (Eds) The expressive organization, Oxford University Press, Oxford.

Kinard, J., Smith, M. E., and Kinard, B. R., (2003) .Business executives' attitudes toward social responsibility: Past and present, American Business Review, 21 (2), 87-91.

King, S., (1991). Brand-building in the 1990s. Journal of Marketing Management, 7 (1), 3-13.

Lichtenstein, D.R., Minette E.D., and Braig, M., (2004). The Effect of Corporate Social Responsibility on Customer Donations to Corporate-Supported Nonprofits. Journal of Marketing, 68, 16- 33.

Luo, X., Bhattacharya, C. B., (2006). Corporate social responsibility, customer satisfaction, and market value, Journal of Marketing, 70 (4), 1-18.

Maignan, I., Ferrell, O.C., (2004). Corporate social responsibility and marketing: An integrative framework, Journal of the Academy of Marketing Science, 32(1), 3-19.

Margolis, J., and Walsh, J.P., (2003). Misery Loves Companies: Rethinking Social Initiatives by Business, Administrative Science Quarterly, 48, 268-305.

McWilliams, A., and Siegel, D., (2001). Corporate Social Responsibility: A Theory of the Firm Perspective", Academy of Management Review, 26 (1), 117-127.

McWilliams, A., Siegel, D., (2001). Corporate social responsibility: A theory of the firm perspective, Academy of management Review, 26 (1), 117-127. 
Mercer, J., (2003). Corporate social responsibility and its importance to consumers, PhD. Thesis, The Claremont Graduate University, USA.

Merrilees, B., Miller, D., (2008). Principles of corporate rebranding, European Journal of Marketing, 42 (5/6), 537-552.

Miles, M.P., Govin, J.G., (2000). Environmental marketing: A source of reputational, competitive, and financial advantage, Journal of Business Ethics, 23 (3), 299-311.

Miller, D., (2008). Retail marketing: A branding and innovation approach. European Journal of Business and Social Sciences, 4(10), 4454.

Miller, D., (2008). Retail marketing: A branding and innovation approach. Prahran, Vic: Tilde

Mitchell, R. K., Agle, B.R., and Wood, D.J., (1997). Toward a Theory of Stakeholder Identification and Salience: Defining the Principle of Who and What Really Counts, Academy of Management Review, 22 (4), 853-886.

Mushanyuri, B.E., (2013). The impact of corporate social responsibility on sustainable supply chains; a review of literature, European Journal of Business and Social Sciences, 1(10), 52-60.

Pava, M.L., and Krausz, J., (1996). The Association between Corporate Social Responsibility and Financial Performance: The Paradox of Social Cost, Journal of Business Ethics, 15, 321-57.

Pinnington, A., Macklin, R., Campbell, T., (2007). Human Resource Management: Ethics and Employment, Oxford, Oxford University Press.

Porter, M.E., and Kramer, M.R., (2006). Strategy and Society. Prentice Hall, New Jersey.

Post, E., Preston, E., and Sachs, S., (2002). Managing the Extended Enterprise: The New Stakeholder View, California Management Review, 45(1), 6-28.

Pratt, M. G., (1998). To be or not to be: central questions in organizational identification. In Whetten, D. A., \& Godfrey, P. C., (1998). Identity in organization. Thousand Oaks: Sage.

Reddy, A.C., \& Campbell, D.P., (1993). Positioning Hospitals: A Model for Regional Hospitals. Journal of Healthcare Marketing, 13(1), 40-44.

Roberts, P.W., Dowling, G.R., (2002). Corporate reputation and sustained superior financial performance, Strategic Management Journal, 23(12), 1077-1093.

Rupp, D. E., Gananpathy, J., Aguilera, R. V., and Williams, C. A., (2006). Employees' reactions to corporate social responsibility: an organizational justice framework. Journal of Organizational Behaviour, 27, 537-543.

Schmidt, K., and Ludlow, C., (2002). Inclusive Branding: The why and how of a holistic approach to brands. Basingstoke, Palgrave Macmillan.

Sen, S., Bhattacharya, C. B., Korschun, D., (2006). The role of corporate social responsibility in strengthening multiple stakeholder relationships: A field experiment. Journal of the Academy of Marketing Science, 34 (2), 158-166.

Smidts, A., Pruyn, H., and van Riel, B.M., (2001). The impact of employee communication and perceived external prestige on organizational identification. Academy of Management Journal, 44 (5), 1051-1062.

Smith, N.C., (2003). Corporate Social Responsibility: Whether or How? California Management Review, 45 (4), 52-76.

Stoney, C., and Winstanley, D., (2001). Stakeholding: Confusion or utopia? Mapping the conceptual terrain. The Journal of Management Studies, 38(5), 603-626.

Swanson D. L., (2008). Top managers as drivers for corporate social responsibility. In: A. Crane, D. Matten, A. McWilliams, J. Moon \& D. Siegel (Eds.). The Oxford Handbook of Corporate Social Responsibility: 227-248.Oxford, UK: Oxford University Press.

Swanson, D. L., and Niehoff, P., (2001). Business citizenship outside and inside organizations. In: J.Andriof \& M. Mclntosh, eds., Perspective on Corporate Citizenship: 104-116.Sheffield, UK: Greenleaf Publishing.

Tadevosyan, L., Mazzucato, L., and Kos-Hansen, O., (2008). Corporate Brand Positioning, Master Thesis, Lund University. Sweden.

Thorne, M., Ferrell, O., and Ferrell, L., (2005). Business and Society: A strategic Approach to Social Responsibility, Houghton Mifflin, MA. University. York.

Uggla, H., 2006. The corporate brand association base, European Journal of Marketing, 40 (7/8), 785-802.

Vaaland, T., Heide, M., Gronhaug, K., (2008). Corporate social responsibility: Investigating theory and research in the marketing context, European Journal of Marketing, 42(9/10), 927-953.

Waldman, D. W., \& Siegel, D. S., (2008). Defining the socially responsible leader. The Leadership Quarterly, 19(1), 117-131.

Werther Jr, W. B., Chandler, D., (2005). Strategic corporate social responsibility as global brand insurance, Business Horizons, 48 (4), 317-324.

Wood, D.J., (1991) Corporate Social Performance Revisited. Academy of Management Review16, 691-718.

Xie, H.Y., Bogs, D.J., (2006). Corporate branding versus product branding in emerging markets. Marketing Intelligence \& Planning, 24(4), 347-364.

York, J., (2009). Pragmatic sustainability: Translating environmental ethics into competitive advantage, Journal of Business Ethics, 85, 97-109.

Zineldin, M., and Bredenlow, T., (2001). Performance measurement and management control positioning strategies, quality and productivity: A case study of a Swedish bank, Managerial Auditing Journal 6(9), 484-89. 